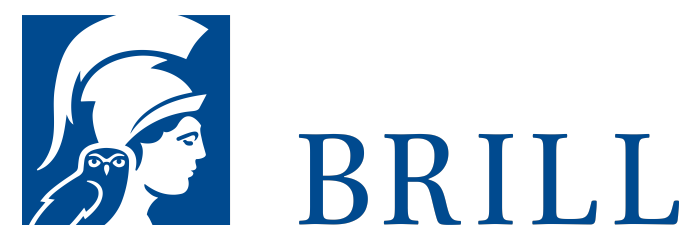

\title{
Jesuit Image Theory
}

Authors: Wietse de Boer, Karl A.E. Enenkel, and Walter Melion

The Jesuit investment in images, whether verbal or visual, virtual or actual, pictorial or poetic, rhetorical or exegetical, was strong and sustained, and may even be identified as one of the order's defining characteristics. Although this interest in images has been richly documented by art historians, theatre historians, and scholars of the emblem, the question of Jesuit image theory has yet to be approached from a multi-disciplinary perspective that examines how the image was defined, conceived, produced, and interpreted within the various fields of learning cultivated by the Society: sacred oratory, pastoral instruction, scriptural exegesis, theology, collegiate pedagogy, poetry and poetics, etc. The papers published in this volume investigate the ways in which Jesuits reflected visually and verbally on the status and functions of the imago, between the foundation of the order in 1540 and its suppression in 1773 . Part I examines texts that purport explicitly to theorize about the imago and to analyze its various forms and functions. Part II examines what one might call expressions of embedded image theory, that is, various instances where Jesuit authors and artists use images implicitly to explore the status and functions of such images as indices of image-making.

Contributors include Wietse de Boer, James Clifton, Ralph Dekoninck, Karl Enenkel, Pierre Antoine Fabre,...

See More

\section{Readership}

all those interested in Jesuit Studies, History of Religion, Art history, History of Images, Image Theory, Poetics, Rhetoric, Catholic Reform, Counter-Reformation

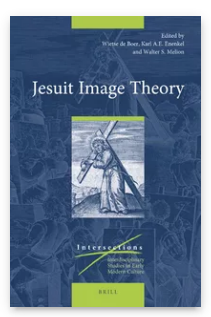

Pages: 518 pages, incl 97 (full-color) images

Language: English

Subjects: Early Modern History, History, Aesthetics \&

Cultural Theory, Philosophy, General, Art History, Art History, History Publisher: Brill

Series:

Intersections,

Volume: 45

E-Book (PDF)

Released online: 10 Jun 2016

ISBN: 978-90-

04-31912-7

List price

USD $\$ 235.00$

Hardback

Publication date:

o9Jun 2016

ISBN: 978-90-

04-31911-O

List price

USD $\$ 235.00$ 
WIETSE DE BOER is Professor of History at Miami University (Ohio). His research is focused on the history of the Italian Counter-Reformation. His recent and current projects explore the intersections between religion and sense experience.

Publications on this theme include Religion and the Senses in Early Modern Europe, co-edited with Christine Göttler.

KARL ENENKEL is Professor of Medieval Latin and Neo-Latin at the University of Münster. Previously he was Professor of NeoLatin at the University of Leiden. He has published widely on international Humanism, early modern culture, paratexts, literary genres 1300-16oo, Neo-Latin emblems, word and image relationships, and the history of scholarship and science.

WALTER MELION is Asa Griggs Candler Professor of Art History at Emory University. He has published extensively on Dutch and Flemish art and art theory of the 16th and 17th centuries, on Jesuit image-theory, on the relation between theology and aesthetics in the early modern period, and on the artist Hendrick Goltzius.

For more information see brill.com

Order information: Order online at brill.com +44330 333 oo49 | customerservices@brill.com Submission information: brill.com/authors

Titles published by Brill | Fink, Brill | mentis or Brill | Schöningh: +49(o)71 5413279216 | brill@brocom.de 